\title{
Differential accumulation of U1 and U4 small nuclear RNAs during Xenopus development
}

\author{
Elsebet Lund and James E. Dahlberg \\ Department of Physiological Chemistry, University of Wisconsin-Madison, Madison, Wisconsin 53706 USA
}

\begin{abstract}
We showed previously that those U1 small nuclear RNA (snRNA) genes of Xenopus laevis which are transcribed very actively in early embryos are quiescent in mature (stage VI) oocytes (Forbes et al. 1984). Although that study demonstrated that differential control of snRNA genes occurred, it did not describe snRNA accumulation during development. Using high-resolution polyacrylamide gels in combination with Northern blot hybridization and RNA sequence analyses, we show here that Xenopus has at least three classes of U1 and U4 snRNAs that are distinguishable by their differential expression of oocytes, embryos, tadpoles, and frogs. Adult snRNAs appear to be synthesized constitutively throughout Xenopus development and comprise the major species in tissues from large tadpoles and frogs. Embryonic snRNAs are the principal species accumulating during the two periods of rapid snRNA synthesis, i.e., in previtellogenic oocytes and early embryos. Tadpole RNAs are minor species that are most prominent in young feeding tadpoles. Transcription of both embryonic and adult snRNA genes is activated at the midblastula transition (MBT), but expression of the embryonic genes is switched off selectively within a few days after MBT. Although the precise timing of this inactivation differs significantly for $U 1$ and $U 4$ genes, the overall pattern of differential expression is common to $\mathrm{U} 1$ and $\mathrm{U} 2$ snRNA genes. Because of sequence differences between the snRNAs accumulating at various stages, the resulting populations of snRNPs could have different splice-site specificities leading to altered patterns of pre-mRNA splicing during development.
\end{abstract}

[Key Words: U1 snRNA; U4 snRNA; developmental control of snRNAs; transcription of snRNAs; Xenopus laevis; small nuclear RNAs]

Received November 4, 1986; accepted November 26, 1986.

At particular periods in Xenopus development, the need for rapid accumulation of small nuclear RNAs (snRNAs) becomes very pronounced. For example, after the midblastula transition (MBT) (Newport and Kirschner 1982), when the blastomeres are still dividing rapidly, the synthesis of large amounts of snRNAs is required (Forbes et al. 1983). In the case of Ul snRNA, this requirement is met by transcription of a large family of embryonic U1 RNA genes (Forbes et al. 1984). The resulting U1 RNAs differ slightly in sequence from the majority of the Ul RNAs expressed in cells from differentiated tissues (e.g., kidneyl, suggesting that the expression of the embryonic genes might serve other functions than simply to furnish sufficient amounts of snRNAs. Since most of the major species of snRNAs, including U1, U2, U4, U5, and U6, participate in the splicing of pre-messenger RNAs (pre-mRNAs) (for review, see Padgett et al. 1986 and references therein), we and others have proposed that differential expression of snRNA genes during development might be responsible, in part, for selection of alternative splice sites during pre-mRNA processing (Forbes et al. 1984; Lund et al. 1985; Laski et al. 1986).
Cultured Xenopus laevis cells contain more than seven different electrophoretically separable species of U1 RNA. We previously showed that two of these RNAs, called xU1b1 and xU1b2 (formerly xU1a and xU1b, respectively; Lund et al. 1984; Ciliberto et al. 1985; Krol et al. 1985), account for more than $95 \%$ of the U1 RNAs synthesized during early embryogenesis; hence, they are referred to as embryonic U1 RNAs. A different subset of RNAs, called xUlal to xUla5 (formerly called $x U 1 c-g$, respectively), is synthesized in tissue culture cells and in mature stage VI oocytes (Forbes et al. 1984); these are called adult U1 RNAs. Although it has been shown that large amounts of U1 (and U2) snRNAs accumulate during early oogenesis (Forbes et al. 1983; Fritz et al. 1984), it is not known whether the U1 RNAs synthesized in immature and mature oocytes are the same.

The two $\mathrm{xU} 1 \mathrm{~b}$ genes are arranged pairwise in large tandem arrays and are present in over 500 copies per haploid genome. In contrast, the $\mathrm{xU}$ la genes appear to be more dispersed and present in less than 10 copies each (Lund et al. 1984; Zeller et al. 1984). 
To delimit precisely the stages at which the different classes of U1 genes are expressed, we have examined the patterns of accumulation of xUla and xUlb RNAs throughout Xenopus development. Our results demonstrate that $\mathrm{xU}$ la RNAs are present in all transcriptionally active tissues investigated, whereas the two xUlb RNAs accumulate almost exclusively in previtellogenic oocytes and in early embryos. We also show that this pattern of developmental control extends to another family of Xenopus snRNA genes, encoding U4 RNAs. Furthermore, we present evidence for a third class of $\mathrm{xU} 1$ and $\mathrm{xU} 4$ RNAs, which accumulate mostly in tadpoles.

\section{Results}

To determine which classes of U1 RNAs were present in various tissues during Xenopus development we have taken advantage of the striking separation of the different species of $X$. laevis U1 RNAs, which can be obtained in a nondenaturing gel (Forbes et al. 1984; Lund et al. 1984). The separated RNAs, which we have characterized previously by RNA sequence analyses (Forbes et al. 1984), were detected by Northern blot hybridization using a U1 RNA-specific probe derived from a human Ul gene (Lund and Dahlberg 1984).

\section{Embryonic U1 RNAs are stockpiled in oocytes and accumulate in early embryos}

Although the expression of the $\mathrm{xUla}$, or so-called adult, RNAs predominates in mature stage VI oocytes (Forbes

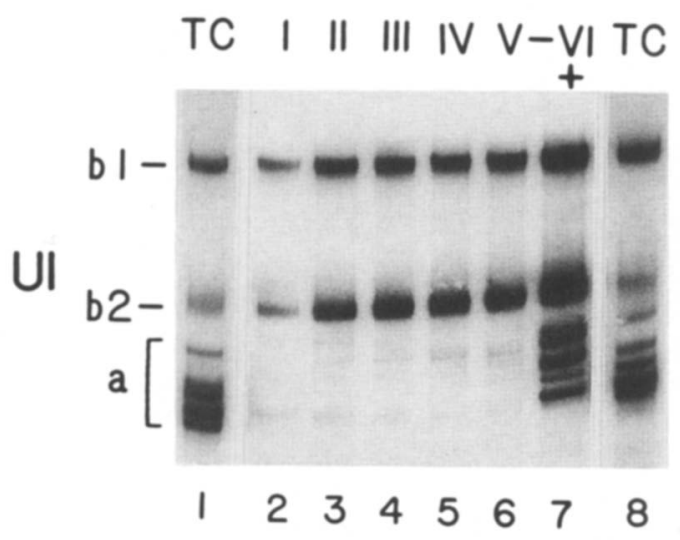

Figure 1. The stockpile of U1 RNAs in oocytes consists of embryonic RNAs. Northern blot analysis of the U1 RNAs that accumulate during oogenesis. (Lanes 2-6) RNAs of 2.5 defolliculated oocytes of the stages indicated (Dumont 1972); (lane 7) RNAs from about three stage V-VI oocytes plus $(+\mid$ follicle cells; (lanes 1 and 8 ) RNAs of about $10^{4}$ frog tissue culture (TC) cells. Total RNAs were separated by electrophoresis in a $15 \%$ (19:1) nondenaturing polyacrylamide gel and transferred electrophoretically to Gene Screen Plus membrane; the blot was hybridized to a ${ }^{32} \mathrm{P}$-labeled U1-specific Sp6 RNA probe. The autoradiogram shown represents a 20 -hr exposure without intensifying screen. et al. 1984), it was unknown which types of U1 RNAs were synthesized in oocytes at earlier stages of development, when 4-8000 somatic cell equivalents of U1 RNAs accumulated (Forbes et al. 1983; Fritz et al. 1984). As shown in Figure 1 (lanes 2-6) almost all of the stored U1 RNAs were of the embryonic (xUlb) type rather than of the adult (xUla) type. Since the amounts of embryonic U1 RNAs per ooctye did not increase significantly between stages II and III (compare lanes 3 and 4) and remained constant thereafter, expression of the embryonic genes appeared to be restricted to the previtellogenic stages of oogenesis. In contrast to oocytes, follicle cells (like other somatic cells, see below) contained primarily adult xUla RNAs (compare lanes 6 and 7; data not shown). Although xUla RNAs are the major species synthesized in stage VI oocytes, these molecules contribute only a very small amount of the U1 RNAs present in mature oocytes.

We previously demonstrated that the synthesis of two embryonic U1 RNAs predominates in late blastula and gastrula embryos (Forbes et al. 1984). The preferential synthesis of these RNAs, as well as the abrupt onset of transcription at MBT (Newport and Kirschner 1982; Forbes et al. 1983), results in the rapid accumulation of xU1b1 and xU1b2 RNAs immediately after MBT (Fig. 2A, lane 3). During the next few days, the level of accumulated embryonic RNAs (per embryo) increased only slightly, apparently reaching a maximum around the hatching or feeding tadpole stage (see lanes 12 and 13, which were exposed for shorter times than lanes 1-11, to reveal the changes in RNA levels). Throughout early embryogenesis, the level of xUlbl RNA exceeded that of $x U 1 b 2$. Presumably, this difference in accumulation resulted from the preferential transcription of $x U 1 b 1$ versus xU1b2 genes (Forbes et al. 1984) due to competition between the two kinds of $\mathrm{xU}$ lb genes (Lund et al., this issue).

\section{Adult U1 RNAs accumulate both in embryos and adult tissues}

The expression of $x U 1$ a genes is readily detectable in late gastrula embryos (Fig. 2A, lane 3) and could also be observed as early as stage 9, in late-blastula embryos (data not shown). This indicates that transcription of both embryonic and adult U1 RNA genes is activated at MBT. However, in contrast to the situation with embryonic RNAs, the adult RNAs continue to accumulate throughout development. If all of the U1 genes were expressed with the same efficiency at MBT, each of the multiple xUla RNAs would account for only $1-2 \%$ of the total U1 RNAs accumulating. Thus, the low levels of the xUla RNA synthesis early in development probably result from the relatively low abundance of xUla genes, which together comprise less than $10 \%$ of all $X$. laevis U1 genes (Lund et al. 1984; Zeller et al. 1984). Because of the continued synthesis of xUla RNAs, concomitant with the slow disappearance of $x U 1 b$ RNAs, the adult RNAs emerge as the major class in tadpoles 
A
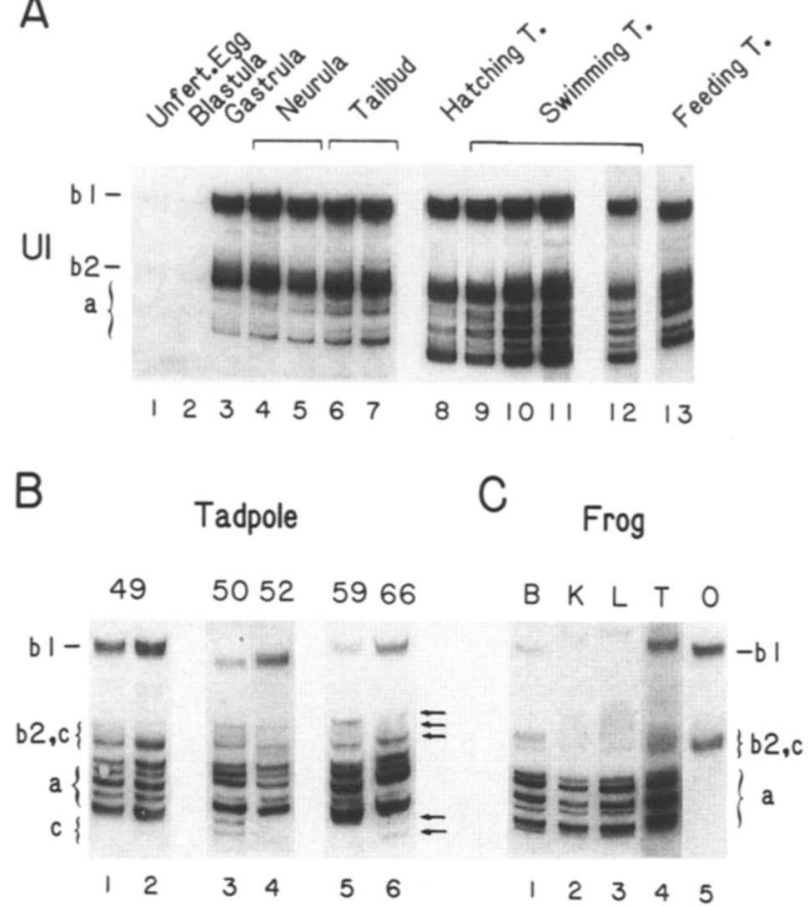

Figure 2. The accumulation of embryonic U1 RNAs is developmentally controlled. Northern blot analyses of the U1 RNAs that accumulate during embryogenesis $(A)$, or in tissues from tadpoles $(B)$ or frogs $(C)$. $(A)$ (Lanes 1-13) Total RNAs corresponding to 0.2 embryos of the stages indicated; (lanes 1-11 and lanes 12 and 13) 40- and 8-hr autoradiographic exposures, respectively; (lanes 11 and 12) the same sample. (B) (Lanes 1-4) Total tadpole RNAs (corresponding to less than 0.1 tadpole); (lanes 5 and 6) total RNAs of tadpole liver. The arrows on the right indicate minor species of $\mathrm{xUlc}$ RNAs which appear to be tadpole specific. $(C)($ Lanes 1-5) Total RNAs of brain (B), kidney $(\mathrm{K})$, liver $(\mathrm{L})$, testis $(\mathrm{T})$, or ovary $(\mathrm{O})$, respectively. Polyacrylamide gel electrophoresis and Northern blot hybridizations were performed as in Fig. 1. The developmental stages, indicated above the lanes in $C$, are according to Nieuwkoop and Faber (1967). In $A$, the stages are 8 (blastula), 12/13 (gastrula), $18 / 19$ and 21/22 (neurula), 26 and 29/30 (tailbud), 35/36 (hatching tadpole), 39/40, 41/42, and 43/44 (swimming tadpole), and 48 (feeding tadpole).

(stages $50-59$ ) or newly metamorphosed froglets (stage 66) (Fig. 2B, lanes 5 and 6).

Adult frog tissues, like liver, brain, and kidney contain almost exclusively xUla RNAs (Fig. 2C, lanes 1-3). However, both testis and ovary have significantly elevated levels of embryonic xUlb RNAs (lanes 4, 5). The presence of $\mathrm{xU} / \mathrm{b}$ RNAs in frog testis resembles the situation in mouse testis (Lund et al. 1985), in which embryonic mU1b RNAs accumulate in large amounts, apparently as a result of expression of embryonic Ul genes in the dividing germ line cells (E. Lund, unpubl.). The predominance of embryonic U1 RNAs in ovaries can be accounted for by a stockpile of xUlb RNAs which is present in stage I and II oocytes (Fig. 1).

\section{Expression of U4 snRNAs is also} developmentally controlled

To determine whether the less abundant U4 RNA, which also participates in pre-mRNA processing (Berget and Robberson 1986; Black and Steitz 1986), might be subject to similar developmental control, Northern blot analyses were performed as above except that the RNAs were separated in partially denaturing polyacrylamide gels (Fig. 3). As was the case with $\mathrm{xU}$ l RNAs, the patterns of accumulated $\mathrm{xU} 4$ RNAs changed strikingly during development and multiple variants of $\mathrm{xU} 4 \mathrm{RNAs}$ accumulated in a coordinate fashion at several stages.

Since the predominant forms of U4 RNAs in tissues from large tadpoles or adult frogs (Fig. 3C,D) appeared to be the same as the two major species in tissue culture cells (Fig. 3A), these RNAs were further characterized by analyses of ${ }^{32} \mathrm{P}$-labeled RNAs isolated from the cultured

A
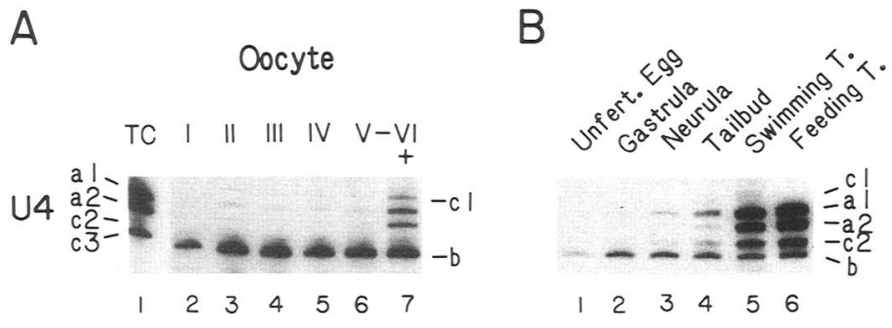

C


Figure 3. Developmental control of $X$. laevis U4 RNA gene expression. Northern blot analyses of xU4 RNAs that accumulate during oogenesis $(A)$ and embryogenesis $(B)$ or in tissues from tadpoles $(C)$ and frogs $(D) .(A)$ (Lanes 2-6) Total RNAs of 2.5 defolliculated oocytes of the indicated stages (Dumont 1972); (lane 7) RNAs of intact stage V-VI oocytes plus (+) follicle cells; (lane 1, TC) RNAs of cultured frog kidney cells. (B) (Lanes 1-6) Total RNAs of 0.2 embryos; the stages (Nieuwkoop and Faber 1967) are 12/13 (gastrula), 21/22 (neurula), 31/32 (tailbud), 43/44 (swimming tadpole), and 48 (feeding tadpole). (C) (Lanes 3-9) Total RNAs of individual tadpoles from a single fertilization; (lanes 10 and 11) total RNAs of tadpole liver. The samples in lane $1(\mathrm{TC})$ and lane $2(48)$ correspond to those of lane 1 of $A$ and lane 6 of $B$, respectively. $(D)$ (Lanes 1-5) Total RNAs of liver $(\mathrm{L})$, kidney $(\mathrm{K})$, brain $(\mathrm{B})$, testis $(\mathrm{T})$, and ovary $(\mathrm{O})$, respectively. Only testis and ovary contain significant amounts of $\mathrm{xU} 4 \mathrm{~b}$ embryonic RNAs. The identities of the various bands of U4 RNAs (al-2, b, and cl-3) are discussed in the text. Total RNAs were separated by electrophoresis in partially denaturing, $12 \%(30: 0.8)$ polyacrylamide gels, containing $7 \mathrm{M}$ urea gels, and the membrane blots were hybridized with the Sp6-U4 RNA probe derived from a human U4 RNA pseudogene (Bark et al. 1985). 

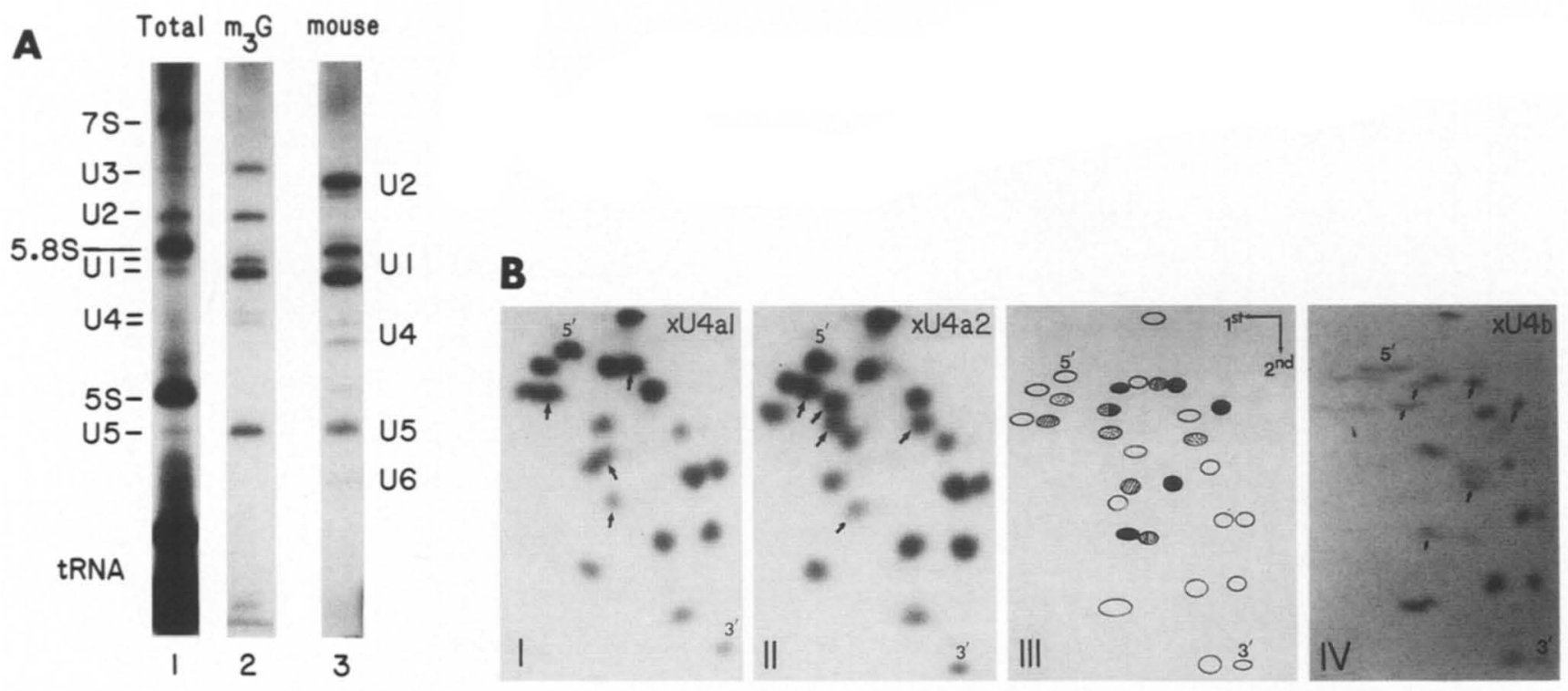

Figure 4. Identification of $X$. laevis embryonic and adult U4 RNAs. Polyacrylamide gel $(A)$ and RNase T1 fingerprint $(B)$ analyses of the U4 RNAs synthesized in Xenopus cultured cells and early embryos (cf. Fig. 5A). (A) (Lanes 1 and 2) Total and anti-m ${ }_{3} \mathrm{G}$ antibodyprecipitable 4-8S RNAs of cultured frog kidney cells. (Lane 3) Markers of mouse snRNAs run in the same gel. Uniformly ${ }^{32} \mathrm{PO}_{4}{ }^{3-}-\mathrm{la}$ beled RNAs from $X$. laevis cultured kidney cells or mouse $\mathrm{Cl} 1300$ cells were separated by electrophoresis in a partially denaturing $12 \%$ (30:0.8), $7 \mathrm{M}$ urea gel as in Fig. 3. The assignments of U1, U2, U4, and U5 snRNAs were by RNase T1 fingerprint analyses (Fig. 4B and data not shown). Note that cognate frog and mouse snRNAs have different gel mobilities. $(B)$ Uniformly ${ }^{32}$ P-labeled xU4 RNAs were purified from cultured cells $(A)$ or early embryos (Fig. 5) (see Materials and methods) and subjected to two-dimensional RNase T1 fingerprinting according to Barrell (1971). Panels I, II, and IV show the fingerprints of xU4a1, xU4a2, and xU4b RNAs, respectively. Panel III is a schematic summary indicating the RNase T1 oligonucleotides which are common to all three xU4 RNAs (open ellipses) or specific to xU4al RNA (hatched ellipses), xU4a2 RNA (dotted ellipses), or xU4b RNA (closed ellipses), respectively. Redigestion with RNase T2 demonstrated that most, if not all, of the xU4a-specific oligonucleotides differed in sequence rather than in the base modification (data not shown). Many of the common oligonucleotides, including those containing the $5^{\prime}$ and $3^{\prime}$ termini, are identical in sequences to those of mouse U4 RNAs (Kato and Harada 1981).

cells. As shown in Figure 4A, both forms of xU4 RNAs were precipitable by anti- $\mathrm{m}_{3} \mathrm{G}$ antibodies (Bringmann et al. 1983) and, when present in snRNPs (Lerner and Steitz 1979), by anti-Sm antibodies (data not shown). Furthermore, RNase T1 fingerprint analyses (Fig. 4B, panels I and II) confirmed that they were distinct, but closely related, variants of U4 RNA. Because the levels of these RNAs are much greater in adult tissues than in early embryos or oocytes (Fig. 3), we call them the xU4a (adult) RNAs. Like the adult xU1 RNAs, both of the $\mathrm{xU} 4 \mathrm{a}$ RNAs were present in follicle cells (compare lanes 6 and 7 of Fig. 3A).

The other major form of $x U 4$ RNA, called $x U 4 b$, was stockpiled in oocytes (Fig. 3A) and accumulated in gastrula embryos, but not during later stages of embryogenesis (Fig. 3B). Analyses of newly synthesized RNAs isolated from pulse-labeled embryos (Fig. 5) demonstrated that $\mathrm{xU} 4 \mathrm{~b}$ RNA was synthesized only during a brief period immediately after MBT but not in early neurula embryos, when other forms of xU4 RNAs could be distinguished (see also Fig. 3B). RNase T1 fingerprinting of the $\mathrm{xU}$ 4b RNA from gastrula embryos (Fig. 4B, panel IV) unequivocally showed that this RNA was a distinct species, differing in sequence from both of the adult xU4a RNAs, as summarized in panel III.
Despite the overall similarity in the patterns of accumulation of $\mathrm{xU} 4 \mathrm{~b}$ and $\mathrm{xU}$ lb RNAs, the synthesis of these RNAs was not strictly coordinated during early embryogenesis. While synthesis of $x U 4 b$ RNA had ceased in early neurula embryos, transcription of the xUlb genes continued at that stage (Fig. 5C; cf. Fig. 2 and Forbes et al. 1984).

\section{A third class of U1 and U4 RNAs accumulates in tadpoles}

A third class of $\mathrm{xU} 1$ and $\mathrm{xU} 4$ RNAs (called $\mathrm{xUlc}$ and xU4c RNAs, respectively) was revealed by analyses of the RNAs accumulating during tadpole development (Figs. 2B, 3B, and 3C). The xUlc and $x U 4 c$ RNAs, like most other classes of $X$. laevis snRNAs, appeared to consist of several variants (c1, c2, and c3). Since the patterns of these RNAs differed in sibling tadpoles of similar developmental age (Fig. 3C and data not shown), it is unlikely that these variants correspond to modified forms of the adult or embryonic RNAs. Thus, this novel class of snRNAs, which is most prominent in tadpoles, apparently is encoded by polymorphic multigene families. 

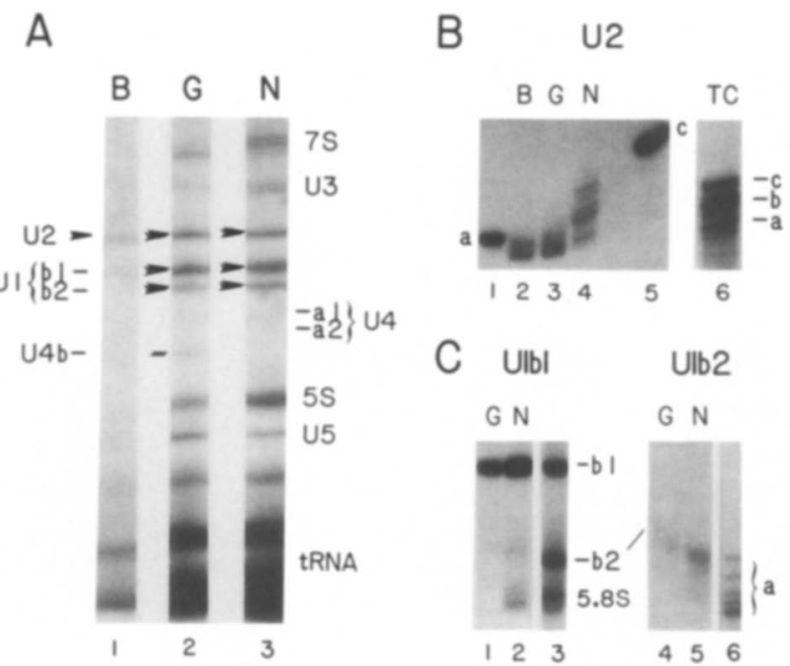

Figure 5. Transcriptional control of embryonic snRNA genes during early embryogenesis. $(A)$ Analyses of the newly synthesized snRNAs accumulating during $M B T$ and late blastula (B, lane 1), gastrula (G, lane 2), or early neurula (N, lane 3). Developing embryos were labeled by injection of ${ }^{32} \mathrm{PO}_{4}{ }^{3-}$ at various stages of development. Total RNAs were isolated from groups of 20 embryos, labeled from stages 7.5-10 (blastula), stage 10-12.5 (gastrula), or stage $12.5-15 / 16$ (neurula), respectively. The total RNAs corresponding to about four embryos were analyzed by gel electrophoresis as in Fig. 3. $(B)$ Comparison of $\mathrm{xU} 2$ RNAs synthesized in embryos (B, G, and N, lanes 2-4) and cultured cells (a, c, and TC, lanes 1, 5, and 6). The U2 RNAs from the bands indicated by arrowheads in $A$ and from the U2 band in lane 1 of Fig. 4A, were re-electrophoresed in $15 \%$ nondenaturing gels as in Fig. 1. The markers (lanes 1 and 5) were the U2 RNAs in bands a and c of lane 6; these two RNAs (plus b) were further characterized by RNA Tl fingerprinting (see text). $(C)$ Developmental control of embryonic xU1 RNA synthesis. (Lanes 1 and 4 and lanes 2 and 5) U1 RNAs synthesized in gastrula (G) or neurula (N) embryos, respectively. The U1 RNAs from bands b1 and b2 (arrowheads) in $A$ were re-electrophoresed in a nondenaturing gel as in $B$. (Lane 3) Markers of xUlbl, $\mathrm{xU} 1 \mathrm{~b} 2$, and $5.8 \mathrm{~S}$ ribosomal RNAs synthesized in injected oocytes; (lane 6) markers of adult xUla RNAs from the fastest migrating band of $x U 1$ RNAs in lane 1 of Fig. 4A.

\section{Modification of U2 RNA is controlled during early embryogenesis}

When snRNAs of uniformly labeled tissue culture cells (Fig. 4) or pulse-labeled embryos (Fig. 5A) were analyzed in partially denaturing gels, only a single band of $\mathrm{xU} 2$ RNA was evident. In contrast, several bands of U2 RNAs could be resolved when the U2 RNAs eluted from these gels were re-electrophoresed in a nondenaturing gel (Fig. 5B). Moreover, the patterns of U2 RNA bands differed between RNAs labeled at various times after MBT (lanes 2-4) and between the RNAs of embryos and cultured cells (lanes 1 and 5). RNase T1 fingerprints of the U2 RNAs from gastrula embryos and tissue culture cells revealed no detectable primary sequence differences, but instead indicated that the RNAs differed at the level of base modification (data not shown). Thus, it is possible that posttranscriptional modification of $X$. laevis U2 RNAs is developmentally controlled.

\section{Discussion}

We have demonstrated that the accumulation of both U1 and U4 snRNAs is developmentally regulated in Xenopus. Three classes of snRNAs could be distinguished according to their accumulation at different stages of development. The adult RNAs (xUa), which appear to be constitutively expressed throughout development, the embryonic RNAs $(x U b)$, which accumulate primarily during oogenesis and early embryogenesis, and the tadpole RNAs $(\mathrm{xUc})$, which, although in low amounts, are most prominent in the feeding tadpole stages.

Developmental regulation of base modifications may also occur. Although electrophoretically separable forms of $\mathrm{xU} 2$ RNAs are detectable, they all appear to have the same primary sequence and to differ primarily in the extent of ribose methylations. The embryonic Ul RNAs of both mice and frogs also show consistent modification differences from the adult Ul RNAs, i.e., the conserved Ap residue at position 70 contains a $2^{\prime} O$-methyl group only in the adult RNAs (Kato and Harada 1985; Lund et al. 1985; our unpublished results).

\section{Function of developmental control of snRNA accumulation}

As a result of the developmental switches described here, the populations of several snRNAs change substantially during development. Moreover, "embryonic" Sm antigens have been detected in Xenopus oocytes, early embryos, and testis (Fritz et al. 1984). Although these proteins have not been shown to be associated specifically with the embryonic snRNAs, which are abundant in these same tissues, that is likely to be the case. It is tempting to speculate that such changes in the complement of snRNPs could alter the patterns of premRNA processing, for example by allowing for alternative splicing to occur.

An additional (or alternative) function for developmental control of snRNA gene transcription appears to be the need for rapid synthesis of large amounts of snRNAs during specific periods in early oogenesis (see below) and embryogenesis (Forbes et al. 1984). In this regard it should be noted that the embryonic (xUlb) genes are at least an order of magnitude more abundant than the adult (xUla) genes (Lund et al. 1984; Zeller et al. 1984).

Embryonic forms of U1 RNAs also accumulate during early mouse development (Lund et al. 1985). In that case there is no need for a high rate of snRNA synthesis since the rate of cell division is not accelerated at any particular stage. Thus, if developmental control of snRNA transcription has a function in mouse embryos, it appears to be needed for accumulation of particular U1 
RNAs, presumably with unique properties, rather than for the production of a large amount of U1 RNAs.

\section{Control during oocyte development}

In stage I and II oocytes (as well as in MBT embryos), the preferential accumulation of the embryonic $\mathrm{xU} 1 \mathrm{~b}$ and xU4b RNAs appears to be a direct result of the relative gene copy numbers (see above). The cessation of $\mathrm{xUlb}$ RNA accumulation prior to stage III of oogenesis indicates that the embryonic genes might be switched off during the stage when lampbrush chromosomes are at their maximum (Dumont 1972; Davidson 1976). Since embryonic xUlb genes injected into stage IV, V, or VI oocytes are transcribed very efficiently (Ciliberto et al. 1985; Krol et al. 1985; Lund et al., this issue; C.J. Bostock and E. Lund, unpubl.), presumably only the genes and not the transcription factor(s) are (temporarily) inactivated at this stage.

The stockpiling of $1-2 \times 10^{9}$ molecules of $\mathrm{xUlb}$ RNAs per oocyte (4-8000 somatic cell equivalents; Forbes et al. 1983) requires a rapid rate of synthesis of these molecules. Since each tetraploid oocyte contains a total of about $4 \times 10^{3}$ copies of embryonic Ul genes and since each gene can be transcribed about 10 times per minute (assuming the RNA polymerase II transcription rates summarized by Davidson 1976), it would take a total of $\left(1-2 \times 10^{9}\right) /\left(4 \times 10^{3} \times 10\right)$ minutes or approximately 20-40 days to generate the stockpile of embryonic snRNAs; this time is commensurate with the length of the previtellogenic stages of oogenesis.

Follicle cells, in contrast to oocytes, contain mainly xUla RNAs (Fig. 1). Since these cells outnumber the oocyte by several thousandfold (Dumont 1972), we were concerned that contamination with transcripts from follicle cells could have accounted for our earlier observation that xUla RNA is synthesized in mature oocytes (Forbes et al. 1984). When stage VI oocytes, which had been injected with radioactive GTP and incubated overnight, were defolliculated, much of the newly synthesized xUla RNA was, in fact, removed with the labeled somatic 5S RNA / which accounted for as much as $50 \%$ of the total labeled 5S RNAs; see also Wakefield and Gurdon 1983) (E. Lund, unpubl.). However, the remainder of the labeled xUl RNAs, which fractionated with oocytes together with all of the labeled oocyte $5 \mathrm{~S}$ RNA, was xUla RNA; little, if any xUlb RNA was found in either fraction. Thus, stage VI oocytes, and not just follicle cells, do synthesize xU1a RNAs.

These results and the data presented earlier (Forbes et al. 1984) indicate that xUlb RNA synthesis is minimal in mature oocytes. Since the level of $x U 1 b$ RNA does not decline in stage VI ooctyes (Fig. 1), we conclude that the turnover of the stockpiled xUlb RNA /which are in snRNPs) must be negligible.

\section{Mechanisms of control of snRNA synthesis during embryogenesis}

During early embryogenesis, the most striking control of snRNA synthesis is the activation of transcription at
MBT (Newport and Kirschner 1982; Forbes et al. 1983). Since accumulation of both adult and embryonic snRNAs occurs at that time (Fig. 2), we conclude that this control is not specific to the embryonic snRNA genes. Shortly thereafter, however, the expression of embryonic snRNA genes apparently is switched off selectively, while transcription of adult (and tadpole) genes continues.

The mechanism(s) responsible for the inactivation of the embryonic (and later presumably also the tadpole) snRNA genes is unknown, but the control of expression of Xenopus oocyte and somatic 5S RNA genes (see, for example, Gottesfeld and Bloomer 1982; Wormington et al. 1982; Brown and Schlissel 1985; Guinta and Korn 1986) serves as an excellent model. By analogy, we propose that in early embryos, immediately after MBT, an excess of transcription factors can support expression of all snRNA genes, but as DNA replication proceeds, competition for these factor(s) becomes established. Under such conditions, the genes that replicate earliest and/or have the highest affinity for the limiting factor(s) would be the ones that continue to be transcribed; for example, we would expect that $\mathrm{xU} 4 \mathrm{a}$ genes would replicate before $\mathrm{xU} 4 \mathrm{~b}$ genes and that affinities for the limiting transcription factor(s) would be in the same order.

We have recently found that cloned $\mathrm{xU}$ Ulb genes are subject to correct transcription controls when injected into embryos (Lund and Dahlberg, in prep.); thus, it is now possible to test directly if the developmental control is mediated as proposed above.

\section{Materials and methods}

Preparation of oocytes and embryos

Adult male and female $X$. laevis frogs were purchased from Xenopus I (Ann Arbor, Michigan), kept at $18^{\circ} \mathrm{C}$, and fed chopped liver three times a week. Unfertilized eggs were isolated as described elsewhere (Lund et al., this issue) and fertilization of freshly laid eggs was carried out according to Newport and Kirschner (1982). Fertilized eggs were allowed to develop at room temperature $\left(22-24^{\circ} \mathrm{C}\right)$ and the developmental stages of embryos and tadpoles were determined according to Nieuwkoop and Faber (1967). Intact stage V and VI oocytes were dissected manually from whole ovaries. Defolliculated oocytes were obtained by incubation of small pieces of ovary in $0.2 \%$ collagenase followed by manual collection of the oocytes of different stages (Dumont 1972).

\section{Isolation of unlabeled RNAs for northern blot analyses}

Total nucleic acids were prepared from oocytes, eggs, or early embryos by homogenization in proteinase $\mathrm{K}$ lysis buffer (Krol et al. 1985; Lund et al., this issue). In the case of larger tadpoles and tissues from frogs, homogenization was in urea lysis buffer as described previously for isolation of RNAs from mouse tissues (Lund et al. 1985).

For Northern blot analyses of U1 RNAs, total RNAs were separated by electrophoresis in nondenaturing gels [containing $15 \%$ (19:1) polyacrylamide, $1 / 2 \times$ TEB $(1 \times$ TEB is $85 \mathrm{~mm}$ Trisborate, pH 8.3, $2.8 \mathrm{mM}$ EDTA); Lund et al. 1983] which are capable of resolving the multiple species of $X$. laevis U1 RNAs (Forbes et al. 1984). For analyses of U4 RNAs, we used partially denaturing gels [containing $12 \%(30: 0.8)$ polyacrylamide, $7 \mathrm{M}$ 
urea and $1 \times$ TEB; Lund et al. 1985] which were found to resolve at least six different forms of $\mathrm{xU} 4$ RNAs.

\section{Northern blot analyses}

Electrophoretic transfer of RNAs to Gene Screen Plus membrane (New England Nuclear), the conditions of hybridization and the Sp6-U1 probe were described earlier (Lund et al. 1985). The Sp6-U4 probe was made by cloning a 64-bp PstI fragment from a human U4 pseudogene (kindly provided by U. Pettersson; Bark et al. 1985) into the pGEMl cloning vector (Promega Biotec). The Sp6 probes were labeled with [32P]GTP (400 $\mathrm{Ci} / \mathrm{mmole}$, Amersham), according to Melton et al. (1984). Autoradiographic exposures of the blots were for $4-40 \mathrm{hr}$ without intensifying screens.

\section{Isolation of labeled RNAs for RNase T1 fingerprint analyses}

For pulse-labeling of embryo RNAs, embryos at various stages of development were injected with $20 \mathrm{nl}$ containing $2 \mu \mathrm{Ci}$ of ${ }^{32} \mathrm{PO}_{4}{ }^{3-}$. After 4-8 $\mathrm{hr}$ of incubation (depending on the stage of development), total nucleic acids were prepared as above.

Uniformly ${ }^{32} \mathrm{P}$-labeled RNAs from cultured frog kidney cells (kindly provided by D.D. Brown) or mouse C1300 cells (Lund et al. 1985) were obtained by incubation of one-half to two-thirds confluent cells (one $75-\mathrm{cm}^{2}$ flask) with $1-2 \mathrm{mCi}$ of ${ }^{32} \mathrm{PO}_{4}{ }^{3-}$ in $10 \mathrm{ml}$ of phosphate-free medium. Total RNAs were prepared as above using urea lysis buffer. Frog snRNAs were identified by precipitation with anti- $\mathrm{m}_{3} \mathrm{G}$ antibody (generously provided by R. Lührmann) according to Bringmann et al. (1983). For further analyses by RNase $\mathrm{T} 1$ fingerprinting, different species of $\mathrm{xU} 2$ and $\mathrm{xU} 4$ RNAs were purified by electrophoresis in two consecutive polyacrylamide gels: a partially denaturing $12 \%(30: 0.8)$, $7 \mathrm{M}$ urea gel followed by a $15 \%(19: 1)$ nondenaturing gel (see above).

Two-dimensional RNase $\mathrm{T} 1$ fingerprinting was done according to Barrell (1971) using homomix C and polyethyleneimine thin-layer plates for the second dimension.

\section{Acknowledgments}

We thank C.J. Bostock for help with pulse-labeling of embryos, J.L. Mitchen for technical assistance with tissue culture cells and tadpoles, and C. Elkins for secretarial assistance. This work was supported by grants from the National Science Foundation (PCM 8309618) and National Institutes of Health (GM 30220) to J.E.D. and E.L.

\section{References}

Bark, C., K. Hammerström, G. Westin, and U. Pettersson. 1985. Non-random integration of human U4 RNA pseudogenes. Mol. Cell. Biol. 5: 943-948.

Barrell, B.G. 1971. Fractionation and sequence analysis of radioactive nucleotides. In Procedures in nucleic acids (ed. G.L. Cantoni and D.R. Davies), vol. 2, pp. 751-779. Harper and Row, New York.

Berget, S.M. and B.L. Robberson. 1986. U1, U2, and U4/U6 small nuclear ribonucleoproteins are required for in vitro splicing but not polyadenylation. Cell 46: 691-696.

Black, D.L. and J.A. Steitz. 1986. Pre-mRNA splicing in vitro requires intact U4/U6 small nuclear ribonucleoprotein. Cell 46: $697-704$.

Bringmann, P., J. Rinke, B. Appel, R. Reuter, and R. Lührmann. 1983. Purification of snRNPs U1, U2, U4, U5, and U6 with 2.2.7-trimethylguanosine-specific antibody and definition of their constituent proteins reacting with anti-Sm and anti-(U1) RNP antisera. EMBO /. 2: 1129-1135.

Brown, D.D. and M.S. Schlissel. 1985. A positive transcription factor controls the differential expression of two 5S RNA genes. Cell 42: 759-767.

Ciliberto, G., G. Buckland, R. Cortese, and L. Philipson. 1985. Transcription signals in embryonic Xenopus laevis U1 genes. EMBO I. 4: 1537-1543.

Davidson, E.H. 1976. Gene activity in early development. Academic Press, New York.

Dumont, J.N. 1972. Oogenesis in Xenopus laevis I. Stages of oocyte development in laboratory maintained animals. $I$. Morphol. 136: 153-180.

Forbes, D.J., T.B. Kornberg, and M.W. Kirschner. 1983. Small nuclear RNA transcription and ribonucleoprotein assembly in early Xenopus development. J. Cell Biol. 97: 62-72.

Forbes, D.J., M.W. Kirschner, D. Caput, J.E. Dahlberg, and E. Lund. 1984. Differential expression of multiple U1 small nuclear RNAs in oocytes and embryos of Xenopus laevis. Cell 38: 681-689.

Fritz, A., R.F. Parisot, D. Newmeyer, and E.M. Robertis. 1984. Small nuclear U-RNPs in Xenopus laevis development: Uncoupled accumulation of the protein and RNA components. J. Mol. Biol. 178: 273-285.

Gottesfeld, J. and L.S. Bloomer. 1982. Assembly of transcriptionally active 5S RNA gene chromatin in vitro. Cell 28: $781-791$.

Guinta, D.R. and L.J. Korn. 1986. Differential order of replication of Xenopus laevis 5S RNA genes. Mol. Cell. Biol. 6: 2536-2542.

Kato, N. and F. Harada. 1981. Nucleotide sequence of nuclear 5.7S RNA of mouse cells. Biochem. Biophys. Res. Commun. 99: $1477-1485$.

1985. New U1 RNA species found in Friend SFFV (spleen focus forming virus)-transformed mouse cells. I. Biol. Chem. 260: 7775-7782.

Krol, A., E. Lund, and J.E. Dahlberg. 1985. The two embryonic U1 genes of Xenopus laevis have both common and genespecific transcription signals. EMBO J. 4: 1529-1535.

Laski, F.A., D.C. Rio, and G.M. Rubin. 1986. Tissue specificity of Drosophila P element transposition is regulated at the level of mRNA splicing. Cell 44: 7-19.

Lerner, M.R. and J.A. Steitz. 1979. Antibodies to small nuclear RNAs complexed with proteins are produced by patients with systemic lupus erythematosus. Proc. Natl. Acad. Sci. 76: 5495-5499.

Lund, E. and J.E. Dahlberg. 1984. True genes for human U1 small nuclear RNAs: Copy number, polymorphism and methylation. I. Biol. Chem. 259: 2013-2021.

Lund, E., C.J. Bostock, and J.E. Dahlberg. 1987. The transcription of Xenopus laevis embryonic U1 genes changes when oocytes mature into eggs. Genes Dev. 1: 47-56.

Lund, E., J.E. Dahlberg, and D.J. Forbes. 1984. The two embryonic U1 snRNAs of Xenopus laevis are encoded by a major family of tandemly-repeated genes. Mol. Cell. Biol. 4: 25802586.

Lund, E., B. Kahan, and J.E. Dahlberg. 1985. Differential control of U1 small nuclear RNA expression during mouse development. Science 229: 1271-1274.

Lund, E., C. Bostock, M. Robertson, S. Christie, J.L. Mitchen, and J.E. Dahlberg. 1983. U1 small nuclear RNA genes are located on human chromosome 1 and are expressed in mouse-human hybrid cells. Mol. Cell. Biol. 3: 2211-2220.

Melton, D.A., P.A. Krieg, M.R. Rebagliati, T. Maniatis, K. Zinn, and M.R. Green. 1984. Efficient in vitro synthesis of biologically active RNA and RNA hybridization probes from 
plasmids containing a bacteriophage SP6 promoter. Nucleic Acids Res. 12: 7035-7056.

Newport, J.W. and M.W. Kirschner. 1982. A major developmental transition in early Xenopus embryos: I. Characterization and timing of cellular changes at the midblastula stage. Cell 30: 675-686.

Nieuwkoop, P.D. and J. Faber. 1967. Normal table of Xenopus laevis (Daudin). North-Holland Publishing Co., Amsterdam.

Padgett, R.A., P.J. Grabowski, M. Konarska, S. Seiler, and P.A. Sharp. 1986. Splicing of messenger RNA precursors. Annu. Rev. Biochem. 55: 1119-1150.

Wakefield, L. and J.B. Gurdon. 1983. Cytoplasmic regulation of 5S RNA genes in nuclear transplant embryos. EMBO $J$. 2: $1613-1619$.

Wormington, W.M., M. Schlissel, and D.D. Brown. 1982. Developmental regulation of Xenopus 5S RNA genes. Cold Spring Harbor Symp. Quant. Biol. 47: 879-884.

Zeller, R., M.-T. Carri, I.W. Mattaj, and E.M. DeRobertis. 1984. Xenopus laevis Ul snRNA genes: Characterization of transcriptionally-active genes reveals major and minor repeated gene families. $E M B O J$. 3: 1075-1081. 


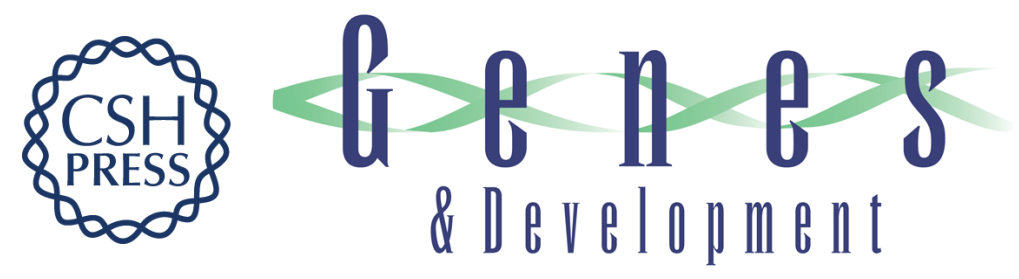

\section{Differential accumulation of U1 and U4 small nuclear RNAs during Xenopus development.}

E Lund and J E Dahlberg

Genes Dev. 1987, 1:

Access the most recent version at doi:10.1101/gad.1.1.39

References This article cites 28 articles, 10 of which can be accessed free at: http://genesdev.cshlp.org/content/1/1/39.full.html\#ref-list-1

License

Email Alerting

Receive free email alerts when new articles cite this article - sign up in the box at the top Service right corner of the article or click here.



